\title{
Transcription Factor TFIIIB Component B" homolog
}

National Cancer Institute

\section{Source}

National Cancer Institute. Transcription Factor T FIIIB Component B" homolog. NCI

Thesaurus. Code C28711.

Transcription factor T FIIIB component B" homolog (2624 aa, $294 \mathrm{kDa}$ ) is encoded by the human BDP1 gene. This protein is involved in RNA polymerase III-dependent gene transcription. 